Jarosław ZALEWSKI

Warsaw University of Technology (Politechnika Warszawska)

\title{
SIMULATION OF A MOTOR VEHICLE MOMENTARILY ACCELERATING IN VARIOUS ROAD CONDITIONS
}

\section{Symulacja ruchu samochodu chwilowo przyspieszającego w różnych warunkach drogowych}

\begin{abstract}
In this paper some selected conclusions have been drawn from the simulated maneuver of a vehicle's momentary acceleration in various road conditions. The aim of this paper was to answer the question whether the random irregularities of the road could decrease the final speed of the vehicle and cause it to deviate from the straight line motion and to what extent. These irregularities had three different maximum amplitudes which enabled analysis of vehicle's acceleration on the less and the more uneven road. Also, almost the same and almost different profiles were assumed for the left and the right wheels of the vehicle's model.

Some additional phenomena such as the ice on the road have been taken into account. The initial speed was $20 \mathrm{~km} / \mathrm{h}$ and after $2 \mathrm{~s}$ the vehicle started to accelerate. Then, after $8 \mathrm{~s}$ the simulation stopped, which gave the whole simulation time equal to $10 \mathrm{~s}$.
\end{abstract}

Keywords: vehicle's acceleration, road irregularities

Streszczenie: $W$ artykule wyciagnięto wybrane wnioski z symulacji manewru chwilowego przyspieszenia pojazdu w różnych warunkach drogowych. Celem artykułu była odpowiedź na pytanie, czy przypadkowe nierówności drogi moga wpływać na zmniejszenie prędkości końcowej pojazdu, a także spowodować jego zboczenie z prostoliniowego toru jazdy oraz w jakim stopniu. Nierówności te miały trzy różne maksymalne amplitudy, co pozwoliło na analize przyspieszenia pojazdu na mniej i bardziej nierównej drodze. Przyjęto również prawie takie same i prawie różne profile dla lewego i prawego koła modelu pojazdu.

Uwzględniono dodatkowe zjawiska, takie jak oblodzenie drogi. Początkowa prędkość wynosiła $20 \mathrm{~km} / \mathrm{h}$ i po 2 s pojazd zaczą przyspieszać. Następnie po 8 s symulacja została zatrzymana, co dało czas całej symulacji równy $10 \mathrm{~s}$.

Słowa kluczowe: przyspieszanie samochodu, nierówności drogi 


\section{Introduction}

One of the most important maneuvers in road traffic is acceleration. The ability to accelerate is essential in vehicles' motion but at the same time it can cause some unpredicted effects, such as the lateral motion or the slip between the wheels and the road. If it cannot be controlled properly or if the road conditions are difficult the accelerating vehicle can drift or lose stability. Another factor that may affect the vehicle's response may be the road conditions. Especially when there are the random irregularities on the road the safe vehicles' flow may be affected. Multiple research on the road traffic safety has so far been related to acceleration in many aspects, e.g. [3, 7].

The aim of this paper is to present the certain considerations on the response of the presented vehicle's model to the disturbances originating from the road while accelerating and then losing the speed with various amplitudes of the road irregularities. Also the influence of road irregularities on the potential lateral motion will be discussed. The vehicle was laden as shown in chapter 2. The simulations have been prepared with the use of MSC Adams/Car software.

Research related to the vehicles' motion reach beyond the ordinary accelerating, which has been presented in this paper as well as in some other works by various authors. For example in [1] analysis of a vehicle following a motorcycle, also in terms of acceleration, has been presented, while in [4] a model of a human driver following another car has been proposed.

As for the road irregularities having the greatest influence, e.g. on a vehicle's vibrations, in [6] the so-called International Roughness Index (IRI) has been used as a factor determining the vibrations of a whole vehicle's body as a function of both the speed and the road category. Dynamics of a motor vehicle on the basis of computer simulations has been examined by the author of this paper in various aspects, e.g. in $[8,9]$.

Research on the means of transport do not always regard the existing solutions. For example in [5] a model of a guideway for a Hyperloop capsule has been presented. On the other hand research on the means of transport can also be related to both maintenance and ecology, as for example in [2] where the selected aspects of using electric vehicles with fuel cells has been considered.

\section{General assumptions for the acceleration maneuver}

A double seater vehicle's model has been used for the presented analysis (fig. 1). This model has previously been used in some papers by the author, e.g. [8, 9]. Here however, both the magnitude and the location of the loading masses was altered. Some general assumptions included the increase of the vehicle's body mass from $995 \mathrm{~kg}$ to $1153 \mathrm{~kg}$ by adding the additional masses representing a driver, a passenger and a baggage. These additional masses have been located in the vehicle's body in such a way that the resulting 
mass-inertia parameters are as presented in table 1 . New coordinates of the center of mass before and after loading have been calculated in relation to the so-called 'origo' point (fig. 2). Similarly, the moments of inertia were calculated relatively to the axes intersecting the 'origo' point (X, Y and $\mathrm{Z}$ respectively) while the moments of deviation were calculated in relation to the pairs of axes intersecting 'origo' ( $\mathrm{XY}, \mathrm{XZ}$ and $\mathrm{YZ}$ respectively).

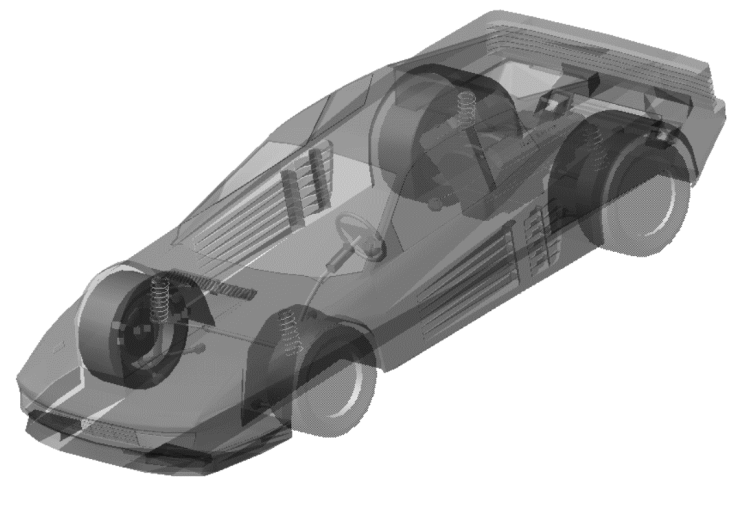

Fig. 1. The vehicle's model used in simulations [MSC Adams/Car]

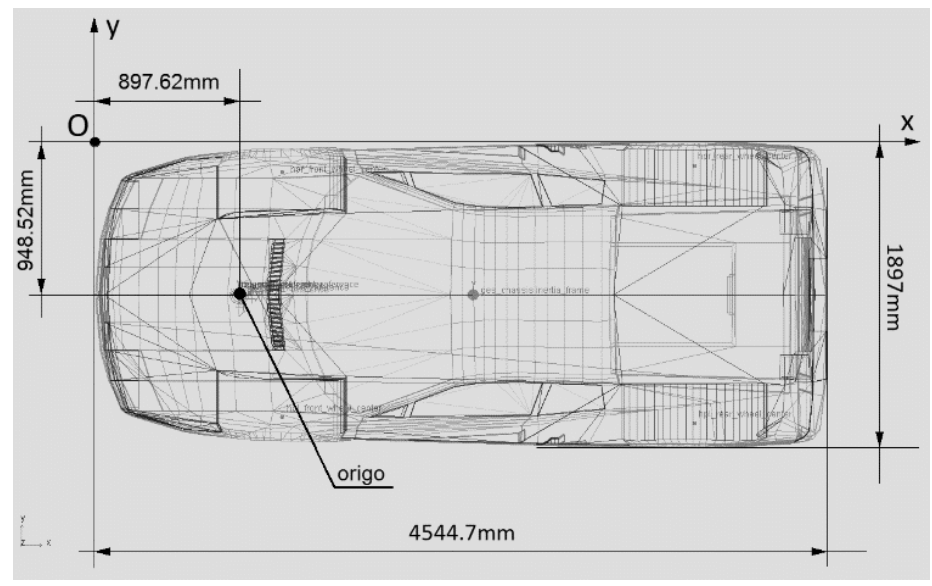

Fig. 2. Location of the 'origo' point and the basic dimensions of the vehicle [on the basis of 9]

If the center of mass of the vehicle's body after loading was determined in relation to the global coordinate system presented in fig. 2 then the results will be useless for further analysis because the global coordinate system is not moving along with the vehicle during the simulation. Hence it is more difficult to analyze the changes of the certain parameters. That is why the calculation of the new location of the center of mass in the laden vehicle's body has been obtained with the use of the 'origo' point which is the origin of a coordinate system located as in fig. 2 but on the road surface and moving along with the vehicle [9]. 
The changes between the unladen and the laden vehicle were not significant, maybe except for the moment of inertia relative to the transverse and the vertical axes passing through the 'origo'. However, here the most important was to load the vehicle in a way reflecting probable configuration of the loading masses (that is why the baggage is close to the longitudinal axis of symmetry of the vehicle's model).

Table 1

Mass - inertia parameters of the unladen simulated vehicle model

\begin{tabular}{|l|l|l|l|l||}
\hline \multirow{2}{*}{} & \multicolumn{2}{|l|}{ Unladen vehicle } & \multicolumn{2}{l|}{ Laden vehicle } \\
\cline { 2 - 5 } & vehicle's body & whole vehicle & $\begin{array}{l}\text { vehicle's } \\
\text { body }\end{array}$ & whole vehicle \\
\hline mass & $995 \mathrm{~kg}$ & $1528 \mathrm{~kg}$ & $1153 \mathrm{~kg}$ & $1686 \mathrm{~kg}$ \\
\hline $\begin{array}{l}\text { center of mass location } \\
\text { relative to the 'origo' } \\
\text { point }\end{array}$ & $\begin{array}{l}\mathrm{xc}=1.5 \mathrm{~m}, \\
\mathrm{yc}=0, \mathrm{zc}=0.45 \\
\mathrm{~m}\end{array}$ & $\begin{array}{l}\mathrm{xc}=1.75 \mathrm{~m},=-0.0014 \mathrm{~m}, \\
\mathrm{zc}=0.43 \mathrm{~m}\end{array}$ & $\begin{array}{l}\mathrm{xc}=1.508 \mathrm{~m}, \\
\mathrm{zc}=0.012 \mathrm{~m},\end{array}$ & $\begin{array}{l}\mathrm{xc}=1.73 \mathrm{~m}, \mathrm{~m}, \\
\mathrm{zc}=-0.007 \mathrm{~m},\end{array}$ \\
\hline moment of inertia (Ix) & $401 \mathrm{~kg} \cdot \mathrm{m}^{2}$ & $583 \mathrm{~kg} \cdot \mathrm{m}^{2}$ & $436 \mathrm{~kg} \cdot \mathrm{m}^{2}$ & $618 \mathrm{~kg} \cdot \mathrm{m}^{2}$ \\
\hline moment of inertia (Iy) & $2940 \mathrm{~kg} \cdot \mathrm{m}^{2}$ & $6129 \mathrm{~kg} \cdot \mathrm{m}^{2}$ & $3361 \mathrm{~kg} \cdot \mathrm{m}^{2}$ & $6550 \mathrm{~kg} \cdot \mathrm{m}^{2}$ \\
\hline moment of inertia (Iz) & $2838 \mathrm{~kg} \cdot \mathrm{m}^{2}$ & $6022 \mathrm{~kg} \cdot \mathrm{m}^{2}$ & $3225 \mathrm{~kg} \cdot \mathrm{m}^{2}$ & $6409 \mathrm{~kg} \cdot \mathrm{m}^{2}$ \\
\hline $\begin{array}{l}\text { moment of deviation } \\
\text { (Ixy) }\end{array}$ & 0 & $-1.9 \mathrm{~kg} \cdot \mathrm{m}^{2}$ & $2.15 \mathrm{~kg} \cdot \mathrm{m}^{2}$ & $1.95 \mathrm{~kg} \cdot \mathrm{m}^{2}$ \\
\hline moment of deviation (Izx) & $671 \mathrm{~kg} \cdot \mathrm{m}^{2}$ & $1160 \mathrm{~kg} \cdot \mathrm{m}^{2}$ & $787 \mathrm{~kg} \cdot \mathrm{m}^{2}$ & $1276 \mathrm{~kg} \cdot \mathrm{m}^{2}$ \\
\hline moment of deviation (Iyz) & 0 & $-1.3 \mathrm{~kg} \cdot \mathrm{m}^{2}$ & $0.64 \mathrm{~kg} \cdot \mathrm{m}^{2}$ & $0.51 \mathrm{~kg} \cdot \mathrm{m}^{2}$ \\
\hline
\end{tabular}

The vehicle's model used here was equipped with the FTIRE (flexible) tires instead of the default PAC89 tires, as it had to perform the motion along the randomly uneven road. Other assumptions regarded the nonlinearity of the vehicle's dampers in its suspension system. The vehicle's body was assumed rigid, since it seemed more essential to observe the vehicle's response rather than its deformations during the maneuver.

The simulations have been performed for the different road conditions. The configurations for the initial speed of $20 \mathrm{~km} / \mathrm{h}$ regarding the weather (dry or icy surface), the amplitudes of irregularities (intensity) and the difference between the road profiles for the left and the right wheels $\left(\right.$ cor $\left._{r l}\right)$ have been presented in table 2. The letter "i" means the configuration for an icy road. 
Table 2

Configurations adopted for the vehicle's acceleration

\begin{tabular}{||c|c|c|c|c|c||}
\hline & \multicolumn{2}{|c|}{ Road } & Intensity & cor $_{\mathrm{rl}}$ & Initial V $[\mathrm{km} / \mathrm{h}]$ \\
\hline configuration 1 & flat & dry & - & - & 20 \\
\hline configuration 1i & flat & icy & - & - & 20 \\
\hline configuration 2 & uneven & dry & 0.5 & 0.2 & 20 \\
\hline configuration 2i & uneven & icy & 0.5 & 0.2 & 20 \\
\hline configuration 3 & uneven & dry & 1.0 & 0.2 & 20 \\
\hline configuration 3i & uneven & icy & 1.0 & 0.2 & 20 \\
\hline configuration 4 & uneven & dry & 1.5 & 0.2 & 20 \\
\hline configuration 4i & uneven & icy & 1.5 & 0.2 & 20 \\
\hline
\end{tabular}

Simulation of the adopted acceleration maneuver with a steering control was performed at an initial speed of $20 \mathrm{~km} / \mathrm{h}$ on the 2 nd gear. The full time of each simulation was $10 \mathrm{~s}$, but the vehicle started accelerating after the first $2 \mathrm{~s}$. The full throttle was activated after $0.5 \mathrm{~s}$ as if the driver had only a short period to increase the speed. Such situations often take place in road traffic. It is also worth noticing that the straight line steering has been activated (fig. 3).

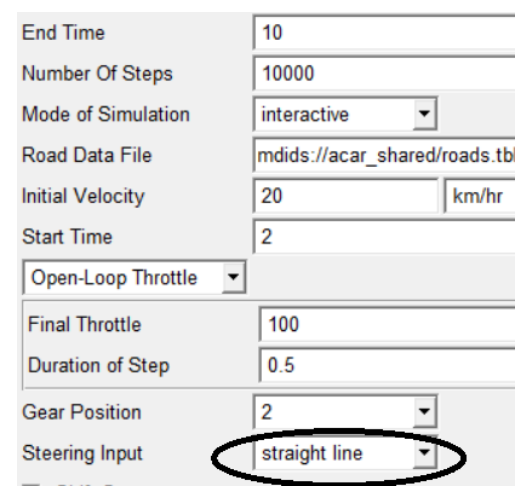

Fig. 3. Adoption of the straight line driver control [based on MSC Adams/Car]

Two parameters (intensity and cor $_{r l}$ ) presented in table 2 are usually included in the files determining the road in Adams/Car [9]. The intensity specifies the maximum amplitude of the road irregularities in a random road profile. Assuming that the wheel did not lose contact with the road, certain results have been obtained after comparing the motion of the wheels along the flat and the uneven road. For the intensity $=0.5$ the maximum amplitudes of the irregularities reached as much as $0.008 \mathrm{~m}$, for the intensity $=1$ they amounted to $0.019 \mathrm{~m}$ and for the intensity $=1.5-$ up to $0.03 \mathrm{~m}$. The higher amplitudes did not allow to perform a simulation of the acceleration maneuver due to the impossibility to integrate the equations of motion of the vehicle's model. The cor $_{r l}$ coefficient specifies the similarity of the irregularities for the left and the right wheels. For the presented case it has been set to 0.2 which means the profiles were almost different which made it more realistic. 


\section{Discussion on the selected results}

At first it seems important to notify that the simulated maneuver has been performed with the steering set to maintain the straight line while accelerating and then losing the speed. However, one of the aims of this paper was to examine whether moving on the more or less uneven road might cause the vehicle to deviate from the potential and desired direction and to what extent. The first set of results can be related to the braking nature of the randomly uneven road. In figs. 4 and 5 the loss of the longitudinal velocity after the $0.5 \mathrm{~s}$ acceleration (reaching $100 \%$ of throttle) has been presented both for the dry and for the uneven road.

As it can be expected, the higher amplitudes of the irregularities, the greater loss of the longitudinal velocity has been observed. In fig. 4 the results for the motion on a dry road show that the initial velocity after stabilizing the motion (at about the 2 nd meter) was about $5.1 \mathrm{~m} / \mathrm{s}$. Then, after having covered $45 \mathrm{~m}$ of the road this velocity dropped to about $3.9 \mathrm{~m} / \mathrm{s}$ for the configuration 1 and down to $3.1 \mathrm{~m} / \mathrm{s}$ for the configuration 4 which shows, that the higher irregularities produced the greater resistance for the wheels of the vehicle.

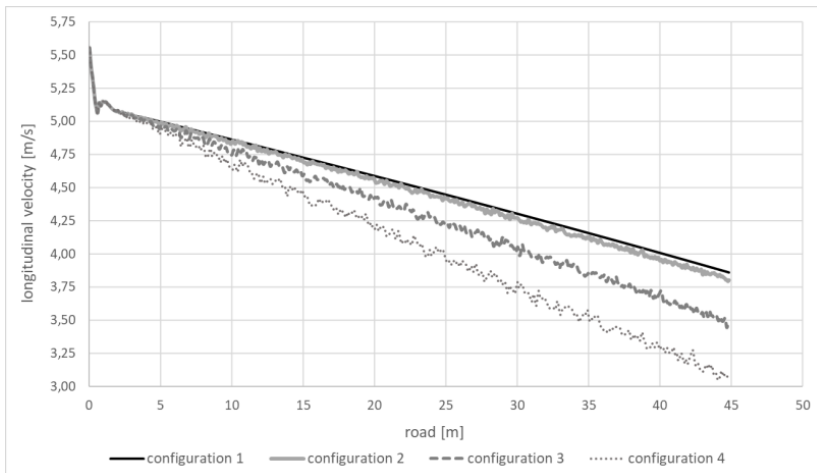

Fig. 4. Longitudinal velocity change due to decreasing the speed on a dry road

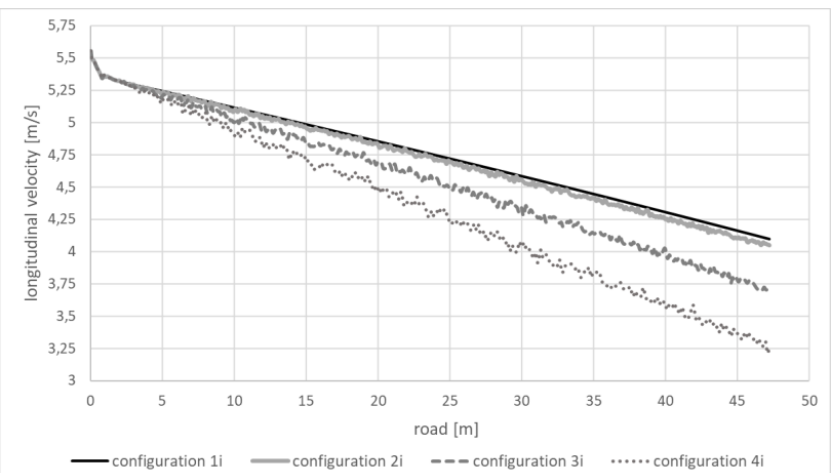

Fig. 5. Longitudinal velocity change due to decreasing the speed on an icy road 
In fig. 5 it can be observed that the vehicle covered a little longer distance (about $47 \mathrm{~m}$ ) which can be a result of the icy road surface. Also the final values of the velocity were a little greater than for the dry road (about $4.12 \mathrm{~m} / \mathrm{s}$ for the configuration 1 and about $3.25 \mathrm{~m} / \mathrm{s}$ for the configuration 4 ). This can pose a piece of evidence that the icy road can cause the lengthening of the distance covered by vehicles moving at the desired initial velocity and that the random irregularities can be a factor acting as an additional resistance originating from the road.

Further part of analysis related the selected aspects of vehicle's response to road disturbances while performing the presented maneuver of a momentary increase in the acceleration.
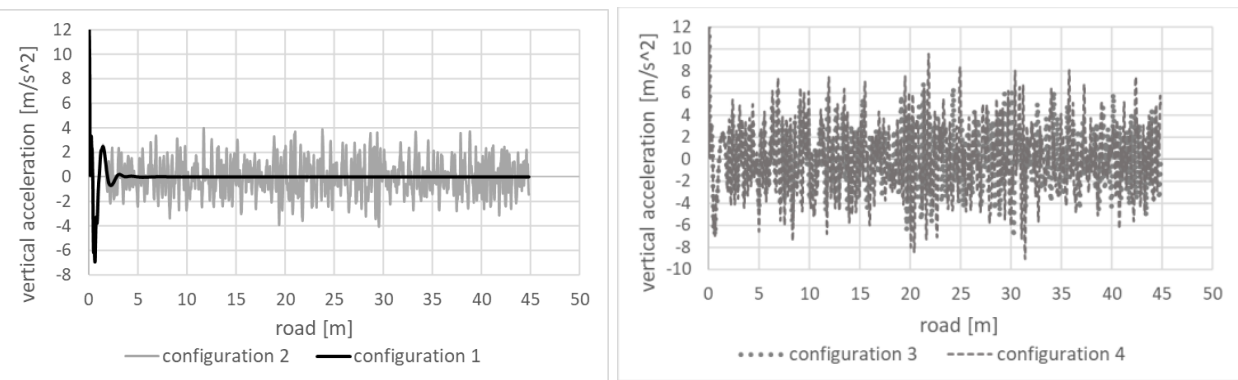

Fig. 6. Vertical acceleration versus the covered distance on a dry road
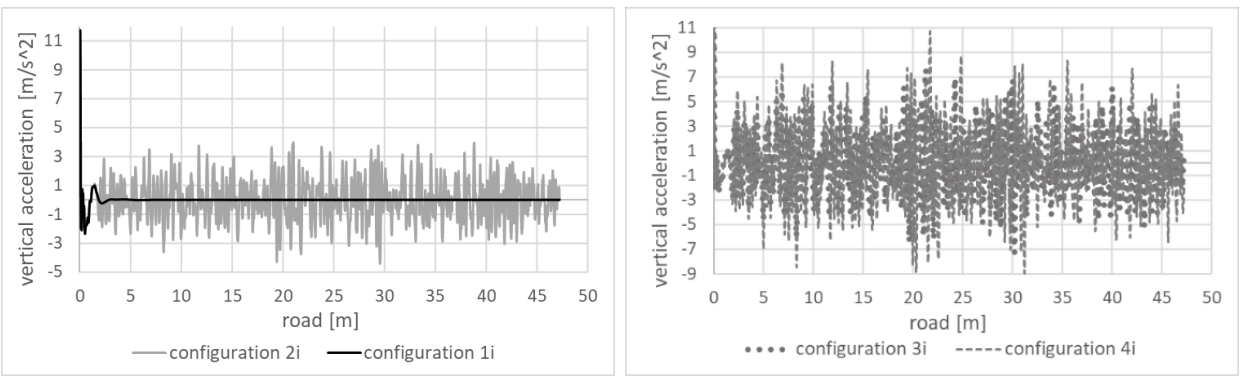

Fig. 7. Vertical acceleration versus the covered distance on an icy road

One of the important aspects of the vehicle's response is the vertical motion along the road with the random irregularities. It is especially crucial when taking the ride comfort or the safety into account.

Although the vertical acceleration on an uneven road is obvious, it seems important to examine if the amplitudes of the irregularities may have any impact on the amplitudes of this acceleration. In fig. 6 the amplitudes of vertical acceleration on the dry road for the less uneven road (left) were similar than those for the icy road (fig. 7, left). The maximum value of this acceleration amounted to $4 \mathrm{~m} / \mathrm{s}^{2}$. Of course, the peaks at the beginning should not be taken into account because this part reflects the beginning of the maneuver. 
The maximum value of the vertical acceleration on the more uneven road (figs. 6 and 7 , right) amounted up to $10-11 \mathrm{~m} / \mathrm{s}^{2}$. Also here the peak at the beginning of the maneuver occurred, which can be related to the full throttle $(100 \%)$ after the first $2 \mathrm{~s}$ of maintaining the constant speed of $20 \mathrm{~km} / \mathrm{h}$.

One of the aims of this paper was to examine the potential changes in the lateral motion of the vehicle, despite the steering set to maintain the straightforward motion. In figs. 8 and 9 the lateral velocity for the motion on the dry (fig. 8) and the uneven road (fig. 9) has been presented.

Although the changes were not significant, the fact that the lateral motion occurred during the acceleration is significant, because the steering was set to maintain the straight line. Of course, the icy road did not produce the significant increase in the lateral velocity, but the irregularities with the higher amplitudes (configurations $3,3 i, 4$ and $4 \mathrm{i}$ ) caused the vehicle to slip to a greater extent than while moving on the less uneven or the flat road (configuration 1, 1i, 2 and 2i).
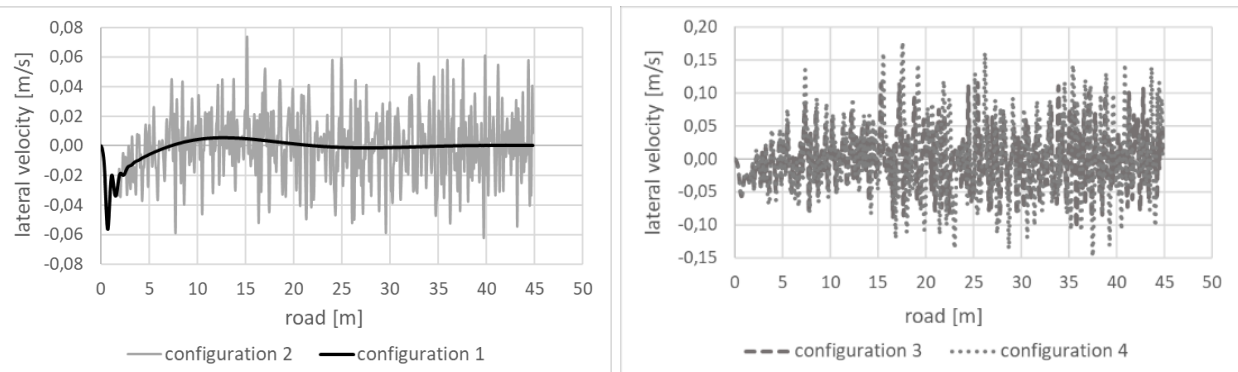

Fig. 8. Lateral velocity versus the covered distance on a dry road
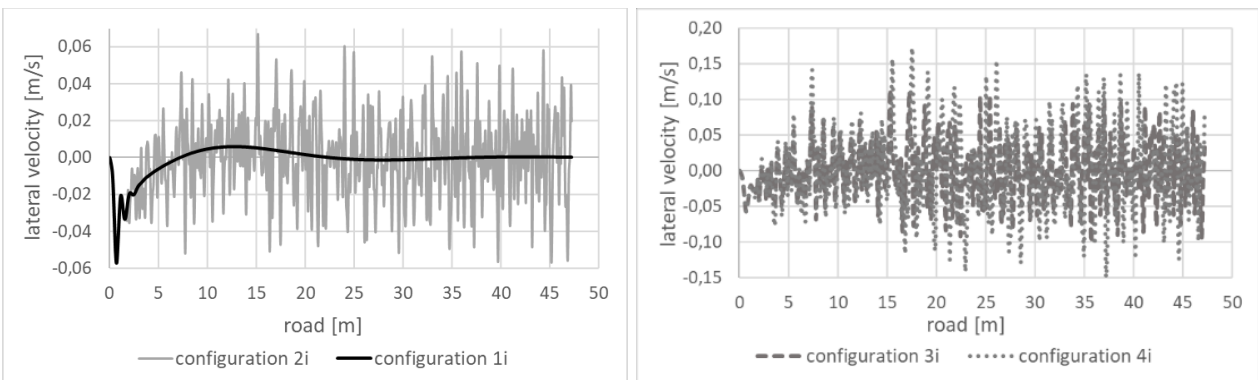

Fig. 9. Lateral velocity versus the covered distance on an icy road

Of course, the icy road caused the lateral velocity to increase by about $0.01 \mathrm{~m} / \mathrm{s}$, but only for the lower amplitudes of the irregularities (configuration 2 and 2i). This means that the higher irregularities on a road may prevent the lateral velocity to increase. What is more, the presented results (figs. 8 and 9, right) show that the icy road caused the distance covered by the vehicle's model to increase by about 2-3 $\mathrm{m}$. 
In order to complete the presented analysis it seems essential to examine if the adopted road conditions could cause deviations in the lateral displacement. In figs. 10 and 11 the lateral displacement versus the covered distance has been presented. As for the motion on the flat road the trajectory for both the dry and the icy road presents only the slight deviation form the straight line resulting probably from the uneven loading of the vehicle's body.

However, the trajectories are not the most important issue here, but the momentary deviations from the black curves obtained for the flat road. It seems that when a vehicle moves on a road with higher amplitudes of the irregularities then it can be harder to control its straightforward motion, as the trajectories in figs 10 and 11 (right parts of these figures relating the configurations $3,3 \mathrm{i}, 4$ and $4 \mathrm{i}$ ) are more turbulent than there obtained for the less uneven road (left parts of both fig. 10 and 11 relating the configurations 1, 1i, 2 and 2i).
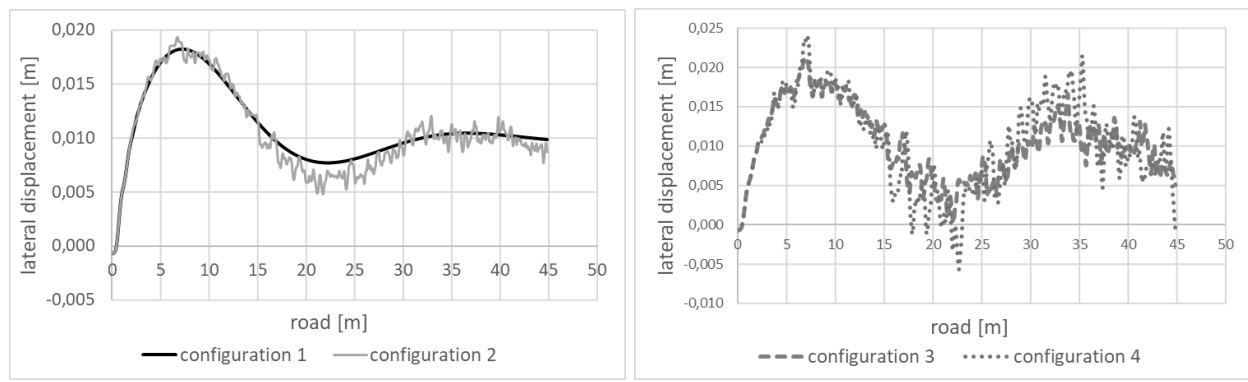

Fig. 10. Lateral displacement versus the covered distance on a dry road
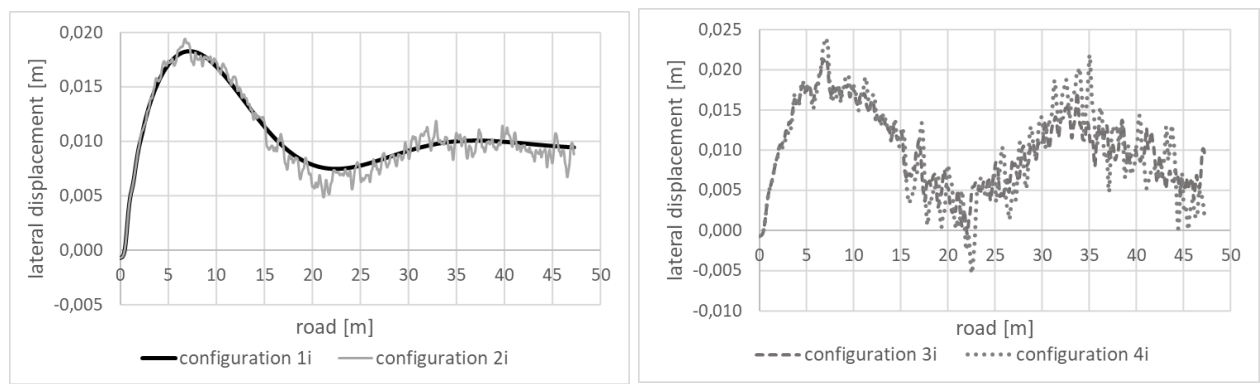

Fig. 11. Lateral displacement versus the covered distance on an icy road

It should be noticed that the presented results relate only the motion along the road with almost different profiles for the left and the right wheels. Also, the initial speed was $20 \mathrm{~km} / \mathrm{h}$ and the time period until the full acceleration lasted only $0.5 \mathrm{~s}(100 \%$ throttle reached after $0.5 \mathrm{~s}$ ). Such attempt to the simulations of vehicles' motion may be considered for the various maneuvers reflecting the possible scenarios in road traffic as well as the various assumptions regarding the road conditions. 


\section{Conclusions}

From the presented results it can be observed that the random road irregularities may in some cases reduce the vehicle's speed and cause the lateral motion due to the external disturbances originating from the road (the random irregularities) as well as the additional conditions (icy or dry road). Although it seems reasonable to conduct research on such problems with the use of the almost different road profiles for the left and the right wheels (e.g. $c o r_{r l}=0.2$ ), the maneuver itself can and will furtherly be modified, e.g. by increasing the time of the full throttle and the amplitudes of the irregularities. Also the normal reactions of the road on the wheels can be analyzed in order to examine, e.g. the ride comfort.

On the other hand it seems interesting how such a vehicle's model would respond to the same disturbances a different initial speed, e.g. $5 \mathrm{~km} / \mathrm{h}$ and $50 \mathrm{~km} / \mathrm{h}$ and if it would cause greater deviations in relation to the potentially straightforward motion.

\section{References}

1. Ehsan A., Masuod T., Ehsan R. K., Mohammadreza A.: A vehicle type-based approach to model car following behaviors in simulation programs (case study: Carmotorcycle following behavior). IATSS Research, Vol. 43, Iss. 1, 2019.

2. Gis W.: Ecological and functional aspects of operation of electric vehicles with fuel cell. Journal of KONBiN, Vol. 50, Iss. 2, 2020, DOI 10.2478/jok-2020-0033.

3. Gonzalez A., O'Brien E.J., Li, Y.-Y., Cashell K.: The use of vehicle acceleration measurements to estimate road roughness, Vehicle System Dynamics, Vol. 46, Iss. 6, 2008.

4. Karim F., Hesham R.: A novel vehicle dynamics and human behavior car-following model: Model development and preliminary testing. International Journal of Transportation Science and Technology, Vol. 9, Iss. 1, 2020.

5. Kisilowski J., Kowalik R.: Displacements of the Levitation Systems in the Vehicle Hyperloop. Energies, 13(24):6595, 2020.

6. Múčka P.: International Roughness Index Thresholds Based on Whole-Body Vibration in Passenger Cars. Transportation Research Record Journal of the Transportation Research Board, 2675(3):1-16, 2020.

7. Yunlong Z., Jinpeng Lv. Wei W.: Evaluation of vehicle acceleration models for emission estimation at an intersection. Transportation Research Part D: Transport and Environment, Vol. 18, January 2013.

8. Zalewski J.: On a Certain Approach Towards the U-Turn of a Motor Vehicle Maneuver. In: Research and the Future of Telematics, Communications in Computer and Information Science, 1289 CCIS, 2020.

9. Zalewski J.: Wpływ wybranych parametrów ruchu na niektóre cechy eksploatacyjne samochodu. ITEE-PIB, Radom 2018. 